\title{
Relationship between marine growth and sea survival of two anadromous salmonid fish species
}

\author{
Arne Johan Jensen, Bengt Finstad, Peder Fiske, Torbjørn Forseth, Audun Håvard Rikardsen, \\ and Ola Ugedal
}

Updated online 5 March 2018: The license for this article has been changed to the CC BY 4.0 license. The PDF and HTML versions of this article have been modified accordingly.

\begin{abstract}
This study found empirical evidence supporting the "growth-survival" paradigm in the marine phase of Arctic char (Salvelinus alpinus) and brown trout (Salmo trutta). The paradigm postulates that larger or faster-growing individuals are more likely to survive than smaller or slower-growing conspecifics. The study employed long-term ( 25 year) capture data from a trap in the River Halselva in Norway during annual migration between marine and freshwater environments. Similar results were found for both species. Growth during the sea sojourn and return rates were positively correlated, linking increased survival with growth. Specific growth rate, survival, and duration of the sea sojourn of first-time migrants were correlated, suggesting that common environmental conditions at sea influence annual fish productivity. Freshwater and sea temperatures affected migration timing, whereas annual variation in marine growth and survival did not correlate with temperatures. This suggests that other factors such as variation in energy intake were the main source of annual growth variations. Moreover, the marine growth rate of the two species may signal annual overall fjord ecosystem production, especially related to their main prey.
\end{abstract}

Résumé : L'étude fait état de preuves empiriques appuyant le paradigme de " croissance-survie » chez les phases marines de l'omble chevalier (Salvelinus alpinus) et de la truite de mer (Salmo trutta). Ce paradigme postule que les individus plus grands ou à croissance plus rapide sont plus susceptibles de survivre que leurs conspécifiques plus petits ou à croissance plus lente. Nous avons utilisé des données de capture de longue durée (25 ans) obtenues d'un piège dans la rivière Halselva, en Norvège, durant les migrations annuelles entre les milieux marins et d'eau douce. Des résultats semblables ont été obtenus pour les deux espèces. Il y a une corrélation positive entre la croissance durant le séjour en mer et les taux de retour, témoignant d'un lien entre un taux de survie plus élevé et la croissance. Le taux de croissance, la survie et la durée du séjour en mer des individus migrant pour la première fois sont corrélés, ce qui donne à penser que des conditions ambiantes communes en mer influencent la productivité annuelle des poissons. Les températures de l'eau douce et de mer ont une incidence sur le moment de la migration, alors que les variations annuelles de la croissance et de la survie en mer ne sont pas corrélées à la température. Cela porte à croire qu'un autre facteur, tel que la variation de l'apport énergétique, constituerait la principale cause de variation de la croissance annuelle. En outre, le taux de croissance en mer des deux espèces pourrait refléter la production annuelle globale de l'écosystème du fjord, particulièrement en ce qui concerne leurs proies principales. [Traduit par la Rédaction]

\section{Introduction}

The "growth-survival" paradigm is influential in the study of marine fish recruitment dynamics (Ottersen and Loeng 2000; Houde 2008; Pepin et al. 2015); it postulates that size, growth rate, or both factors during early life are positively correlated to survival (Anderson 1988). Despite widespread acceptance, little field evidence exists for this hypothesis in larger and older stages of marine fishes. However, some results from studies of anadromous salmonids suggest that a positive relationship between growth and survival may exist during the marine life stage (Friedland et al. 2009). In long-term tagging studies with two Atlantic salmon (Salmo salar) populations in the North Sea, positive correlations were found between growth of post-smolts (i.e., during the first summer at sea) and sea temperature conditions, and high growth led to higher return rates (Friedland et al. 2000). Further, analyses of spacing between scale circuli of coho salmon (Oncorhynchus kisutch) indicated that reduced early marine growth was associated with lower marine survival (Beamish et al. 2004), and similar results have been found for pink salmon (Oncorhynchus gorbuscha) (Holtby et al. 1990; Moss et al. 2005). Moreover, retrospective analyses of circuli spacing from long-term scale-sample data established relationships between post-smolt growth and sea surface temperatures in two European Atlantic salmon populations, again linking growth to abundance and survival (Peyronnet et al. 2007; McCarthy et al. 2008).

Indirect estimates of growth through fish-scale analysis may be influenced by both estimation and sampling biases (Francis 1990), and more direct analyses of growth and survival may provide stronger evidence. Anadromous species, like Arctic char (Salvelinus alpinus) and brown trout (Salmo trutta), conduct the bulk of their lifetime growth over some months during summer at sea, through annual, local migrations to coastal areas near their natal river (Klemetsen et al. 2003; Eldøy et al. 2015; Jensen et al. 2015). Subsequently, with the exception of some pure riverine populations, most individuals are expected to return, overwinter, and spawn in fresh water (Jensen

Received 12 September 2016. Accepted 24 March 2017.

A.J. Jensen, B. Finstad, P. Fiske, T. Forseth, and O. Ugedal. Norwegian Institute for Nature Research (NINA), NO-7485 Trondheim, Norway.

A.H. Rikardsen. Department of Arctic and Marine Biology, Uit - The Arctic University of Norway, NO-9037 Tromsø, Norway.

Corresponding author: Arne J. Jensen (email: arne.jensen@nina.no).

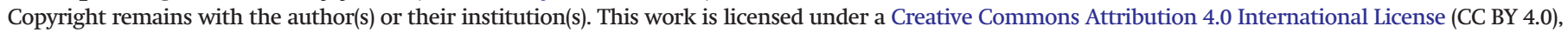
which permits unrestricted use, distribution, and reproduction in any medium, provided the original author(s) and source are credited. 


\section{Pagination not final (cite DOI) / Pagination provisoire (citer le DOI)}

Fig. 1. Map of the study area, with the location of the fish traps in the River Halselva for trapping of all ascending and descending fish.

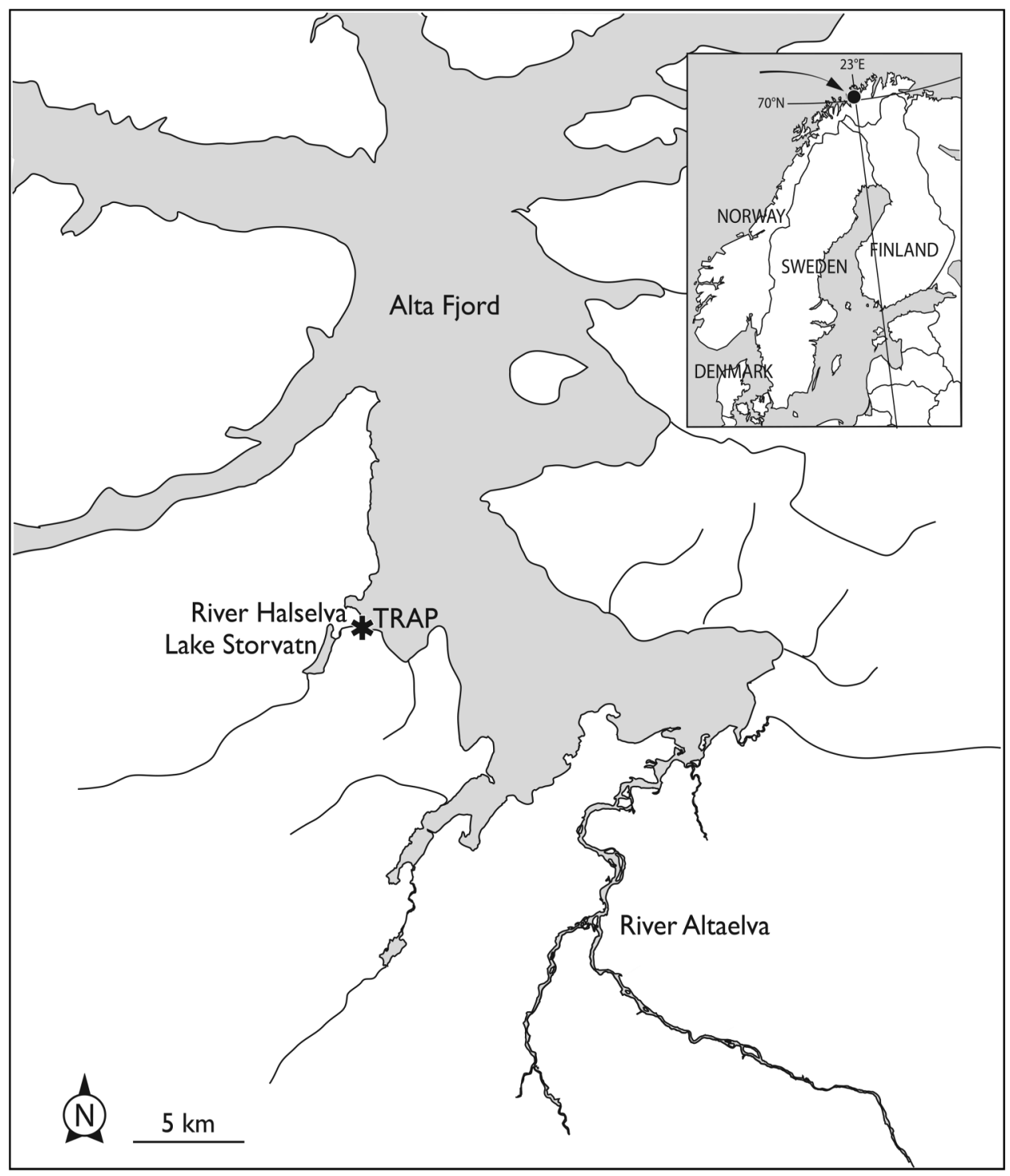

and Rikardsen 2008; Jensen et al. 2014, 2015). Therefore, the brown trout and the Arctic char are more suited than other migratory marine fish for studying relationships between growth and survival across different life-history stages; both variables can be recorded easily at their main feeding habitat, via trapping and enumerating most of the population during their biannual migrations (Elliott 1994; Rikardsen and Elliott 2000; Jensen et al. 2015).

The main objective of this study was to test the hypothesis that marine growth mediates the survival of post-smolts of brown trout and Arctic char. We examined data from a 25 year mark-and-release project at the River Halselva in northern Norway. First-time migrants (smolts) of both species were captured in a permanent fish trap located $200 \mathrm{~m}$ above the outlet to the sea, individually tagged, and thereafter recorded each time they passed the fish trap, usually twice each summer, for the rest of their lives (up to the end of 2012, when the trap was removed from the river). Additionally, we investigated whether climate affected the growth rate, duration of the first sea journey, and timing of descent and ascent to the traps.

\section{Materials and methods}

\section{Study area}

The Hals watercourse $\left(70^{\circ} 2^{\prime} \mathrm{N}, 22^{\circ} 57^{\prime} \mathrm{E}\right)$ in the Arctic region of Norway has a catchment area of $143 \mathrm{~km}^{2}$ and drains into the Alta
Fjord (Fig. 1). Approximately $20 \mathrm{~km}$ of the watercourse is accessible to anadromous salmonids (Arctic char, brown trout, and Atlantic salmon), including a $1.2 \mathrm{~km}^{2}$ lake located $2.1 \mathrm{~km}$ inland and $30 \mathrm{~m}$ above sea level (Lake Storvatn) (Fig. 1). Both bodies of water are ice-covered from December to March or April, a period characterised by low water flow. A pronounced increase in flow occurs during the snow-melting period (May-June) followed by a decrease during July-August, yielding a mean annual flow of $4.3 \mathrm{~m}^{3} \cdot \mathrm{s}^{-1}$. The River Halselva empties directly into the sea without any distinct estuary, resulting in limited freshwater areas for fish to overwinter downstream of the fish traps (see below). Minimum temperature in the River Halselva is around $0{ }^{\circ} \mathrm{C}$ during the icecovered period and then rises steadily until reaching a maximum temperature of approximately $13{ }^{\circ} \mathrm{C}$ in early August. Minimum and maximum sea temperatures are approximately $2.5^{\circ} \mathrm{C}$ in late March and $11^{\circ} \mathrm{C}$ during late July - early August, respectively.

\section{Fish sampling}

During 1987-2012, fish were sampled via permanent fish traps placed $200 \mathrm{~m}$ upstream from the sea: a Wolf trap (Wolf 1951) (apertures $10 \mathrm{~mm}$, inclination 1:10) for descending fish and a fixed box trap for ascending fish. All passing fish larger than $10 \mathrm{~cm}$ were trapped; the Arctic char (sea char) and the brown trout (sea trout) 


\section{Pagination not final (cite DOI) / Pagination provisoire (citer le DOI)}

were predominant in the watercourse, but Atlantic salmon and European eels (Anguilla anguilla) were also present. The traps operated during the ice-free period and were emptied twice per day (at 0800 and $2000 \mathrm{~h}$ ) to record morphological data before release. Body length (natural tip length $L$, in millimetres) and mass $(M$, in grams) were measured for all fish, and sex and sexual maturation were determined with external inspection of all fish, excluding first-time migrants.

The present study included Carlin-tagged (Carlin 1955), $18-28 \mathrm{~cm}$ (approximately 50-250 g) smolts (i.e., first-time migrants, see definition by Allan and Ritter 1977) of brown trout $(n=12682)$ and Arctic char ( $n=10232)$ that migrated to sea before 1 August during 1988-2012. Individuals migrating after 1 August (6.1\% of brown trout and $1.7 \%$ of Arctic char) were omitted because the proportion of parr among descending fish increased in autumn. Data for the cohorts that migrated as smolts during 1990-1993 were also excluded from analyses due to extensive sea-ranching experiments on Arctic char, which may have negatively affected growth of naturally produced fish.

In general, smolts of Arctic char of the Hals watershed migrate before brown trout, with median dates of descent of 25 June and 4 July, respectively, although some individuals of both species leave the river throughout most of the ice-free period of the year (Jensen et al. 2012). The annual descent of naturally produced Arctic char and brown trout smolts numbered, respectively, 500-3600 $($ mean $=1350)$ and 300-1400 $($ mean $=950)$ individuals $($ Jensen et al. 2012).

For both species, survival rate was defined as the return rate of post-smolts to the trap, a significant early sign of overall cohort survival (Jensen et al. 2015).

The standardized mass-specific growth rate ( $\Omega$, percent per day) was used to eliminate the effect of growth rate differences in initial body sizes and was estimated as (Ostrovsky 1995)

$$
\Omega=100 \times \frac{M_{1}^{b}-M_{0}^{b}}{\left(t_{1}-t_{0}\right) \times b}
$$

where $M_{0}$ is body mass at descent from the river, $M_{1}$ is the body mass of the same fish when returning to the river later the same year, $t_{0}$ is the date when the fish descended, $t_{1}$ the date when the fish ascended again, $t_{1}-t_{0}$ is the duration of the stay at sea, and $b$ is the allometric mass exponent for the specific growth rate and body mass relationship (0.31 for brown trout: Elliott et al. 1995). The same value of $b$ was used for Arctic char. $\Omega$ effectively eliminated the effect of growth rate differences in initial body sizes (Sigourney et al. 2008; Finstad et al. 2011; Forseth et al. 2011).

\section{Environmental data}

Temperatures in the River Halselva and the Alta Fjord were measured with temperature loggers every $4 \mathrm{~h}$ during 1987-1998 and every hour during 1999-2012. Tagging experiments with data storage tags indicated that the Hals stock of both Arctic char and brown trout spent more than $90 \%$ of their time at 0-3 m depth at sea (Rikardsen et al. 2007a). Thus, sea temperatures considered representative of both species' marine habitat were taken at a depth of $3 \mathrm{~m}$, approximately $100 \mathrm{~m}$ from shore and $300 \mathrm{~m}$ north of the river outlet.

\section{Statistical analyses}

Statistical analyses were carried out using SPSS version 23, with Pearson's correlation, ANOVA, linear regression, and pairwise $t$ tests.
Fig. 2. Data on brown trout (Salmo trutta) (solid line) and Arctic char (Salvelinus alpinus) (broken line) from the River Halselva during their first sea sojourn. Annual mean values of (a) days at sea, (b) standardized mass-specific growth rate $\Omega$, (c) seasonal growth increment, and (d) return rate of post-smolts to the river.
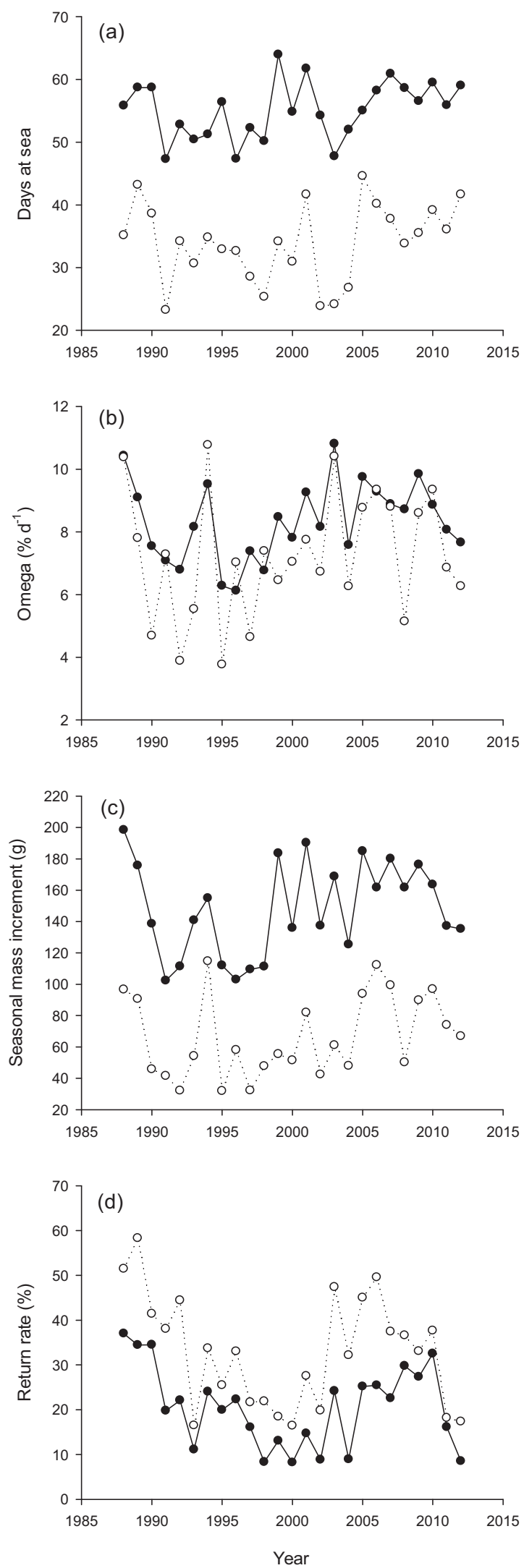

- Published by NRC Research Press 


\section{Pagination not final (cite DOI) / Pagination provisoire (citer le DOI)}

Fig. 3. Relationships between anadromous brown trout (Salmo trutta) and Arctic char (Salvelinus alpinus) from the River Halselva during their first sea sojourn. (a) Duration of the sea sojourn $\left(y=0.875 x-14.4, r^{2}=0.392, F_{[1,19]}=12.3, P=0.002\right)$, (b) standardized mass-specific growth rate $\Omega\left(\% \cdot\right.$ day $\left.^{-1}\right)\left(y=1.14 x-2.08, r^{2}=0.585, F_{[1,19]}=26.8, P<0.001\right)$, $(c)$ growth increment $\left(y=0.587 x-18.4, r^{2}=0.448, F_{[1,19]}=15.4, P<0.001\right)$, and (d) return rate of post-smolts $(\%)$ to the river $\left(y=1.14 x+9.30, r^{2}=0.693, F_{[1,19]}=43.0, P<0.001\right)$.
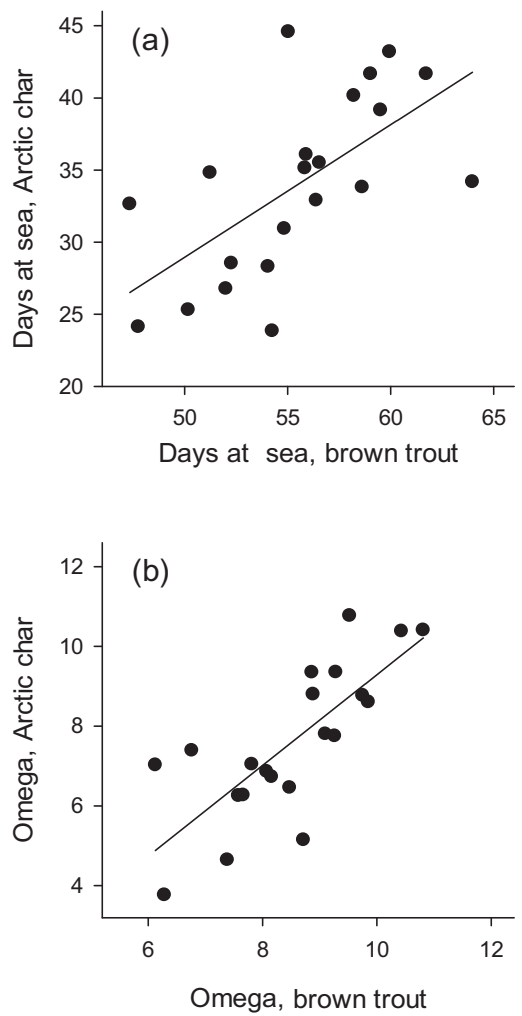

\section{Results}

\section{Growth and survival}

Although no significant temporal trends were detected during the 25 year period regarding duration of the first sea sojourn, standardized mass-specific growth rate $\Omega$, seasonal mass increment, or return rate for any of the two species (Fig. 2, ANOVA tests, $P>0.05$ ), all of these factors were significantly and positively correlated between the two species during their first sea sojourn (Fig. 3).

For both species, significant correlations were found between standardized mass-specific growth rate and return rate (Fig. 4) as well as between mass increase and return rate (Fig. 5), clearly linking increased survival with growth.

The first sea sojourn ( \pm SE) lasted considerably longer for brown trout (mean $55.7 \pm 1.0$ days) than for Arctic char (34.4 \pm 1.4 days), with between-year variations of 47.3-64.0 and 23.8-44.6 days for the former and the latter, respectively (Figs. $2 a$ and $3 a$ ).

Based on the standardized mass-specific growth rate, brown trout grew faster (pairwise $t$ test, $t=3.39, \mathrm{df}=20, P=0.003$ ) during their first sea sojourn (mean $8.51 \% \pm 0.28 \% \cdot$ day $^{-1}$ ) than Arctic char (mean $7.60 \% \pm 0.41 \% \cdot$ day $^{-1}$ ).

The mass increment during the first sea sojourn was considerably higher for brown trout than for Arctic char, mainly because the sea sojourn lasted longer in the former. The mean mass increment of brown trout was $152.7 \pm 6.4 \mathrm{~g}$, with a between-year variation of 103.0-198.4 $\mathrm{g}$ (Figs. $2 c$ and 3c). For Arctic char, the mean mass increment was $71.2 \pm 5.6 \mathrm{~g}$ (variation: 31.8-114.6 g) (Figs. $2 c$ and $3 c$ ).

A higher proportion of Arctic char than brown trout returned to the River Halselva during same summer that they migrated to sea as smolts (Figs. $2 d$ and $3 d$ ). The mean return rate of Arctic char was
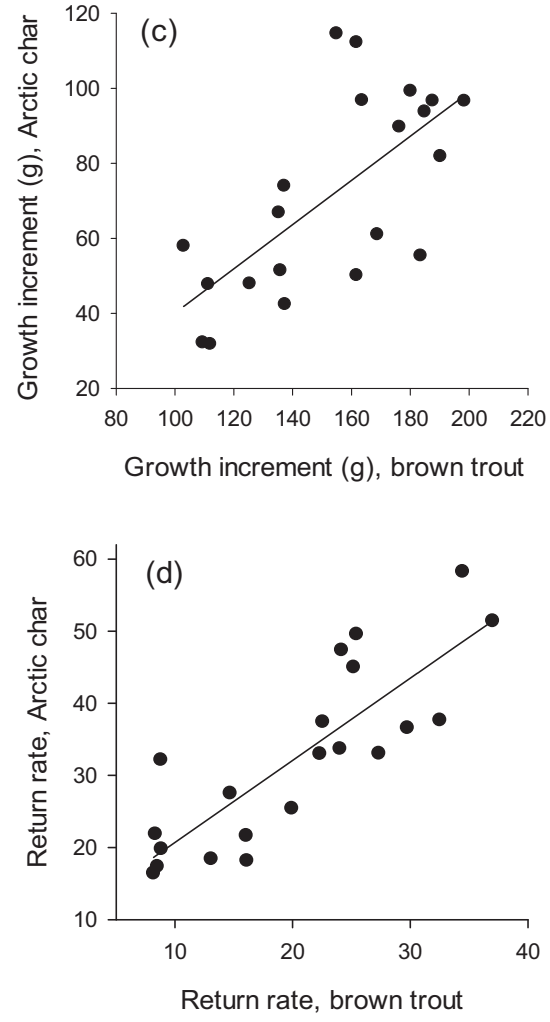

$32.5 \% \pm 2.7 \%$ (between-year variation: $16.4 \%-58.3 \%$ ), while that of brown trout was $20.3 \% \pm 2.0 \%$ (variation: $8.2 \%-37.0 \%$ ).

Duration of the first sea sojourn was significantly related to mass increase during this period for both species (Fig. 6b). However, no significant relationship existed between the duration of the first sea sojourn and standardized mass-specific growth rate (Fig. 6a) or return rate (Fig. 6c).

\section{Environmental correlates}

The timing of the seaward migration was negatively correlated with mean river temperature in June, although this relationship was not significant for brown trout (Fig. 7). A significant negative relationship existed in both species between the mean duration of first sea sojourn and average sea temperatures during August in the Alta Fjord: the first sea sojourn was among the shortest in years with very high average temperatures (Fig. 8). However, no significant relationship was detected between the median date of ascent and Alta Fjord temperatures (Pearson correlation, $P>0.05$ ).

Neither species exhibited a significant relationship in their standardized mass-specific growth rate or return rate and Alta Fjord temperatures (Pearson correlation, $P>0.05$ ). The amongyear variation in sea temperatures during the sea sojourn was small (CV brown trout: 7.8\%, CV Arctic char: 8.5\%).

\section{Discussion}

The present study demonstrates that marine growth and survival are positively correlated in first-time migrants of Arctic char and brown trout, in accordance with other studies suggesting a link between increased growth rate of post-smolts and high sea survival of salmonid fishes (Friedland et al. 2000, 2009; Beamish et al. 2004; Peyronnet et al. 2007). However, these previous studies 
Fig. 4. The relationship between standardized mass-specific growth rate $\Omega\left(\% \cdot\right.$ day $\left.^{-1}\right)$ and return rate of post-smolts in $(a)$ brown trout (Salmo trutta) $\left(y=4.07 x-14.3, r^{2}=0.323, F_{[1,19]}=9.05, P=0.007\right)$ and (b) Arctic char (Salvelinus alpinus) $\left(y=3.91 x+2.80, r^{2}=0.352, F_{[1,19]}=10.31\right.$, $P=0.005)$ to the River Halselva.

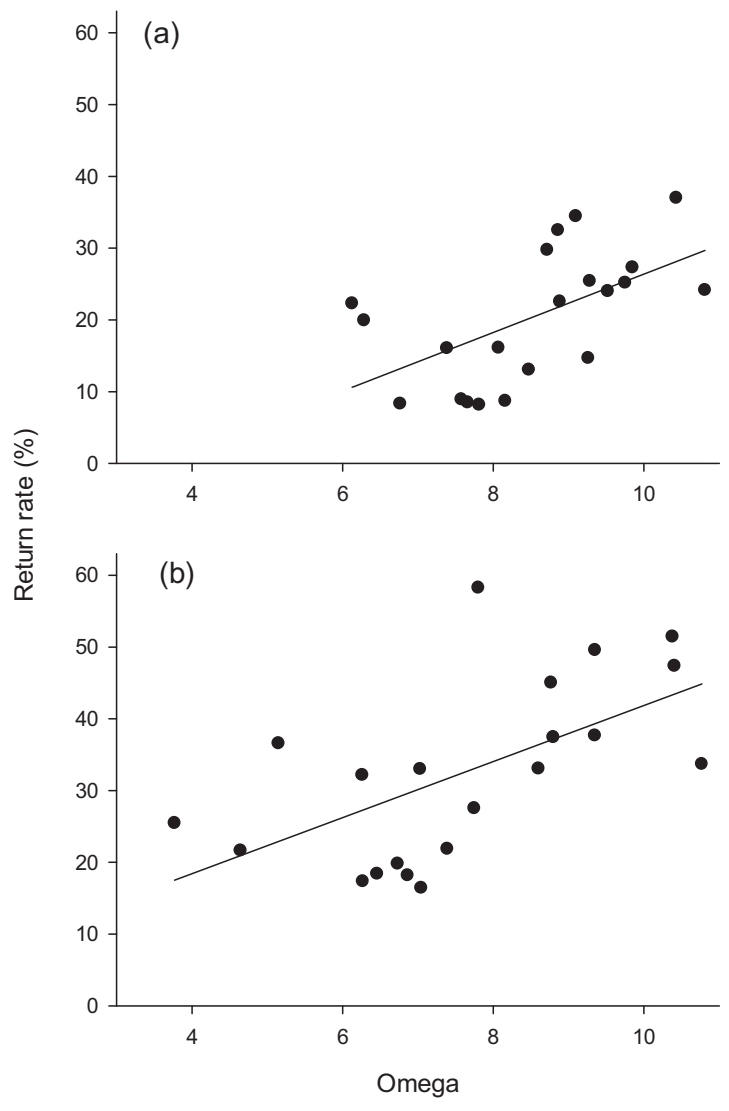

Fig. 5. The relationship between growth increment $M$ during the first sea sojourn and post-sojourn return rate to the river for brown trout $\left(\right.$ Salmo trutta) $(\bullet)\left(y=0.169 x-5.40, r^{2}=0.296, F_{[1,19]}=8.01, P=0.011\right)$ and Arctic char (Salvelinus alpinus) $(\bigcirc)\left(y=0.291 x-11.8, r^{2}=0.362\right.$, $\left.F_{[1,19]}=10.80, P=0.004\right)$.

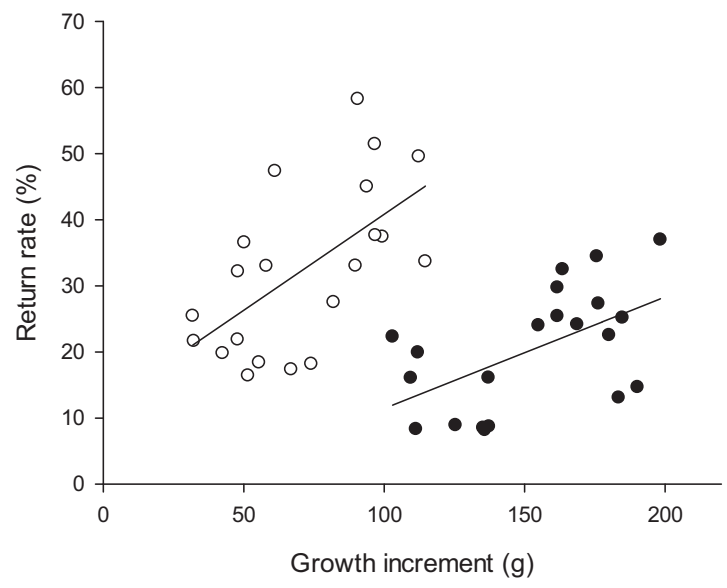

were performed on species that remained over 1 year at sea before returning to their natal rivers, and most (but see Friedland et al. 2000) were based on back-calculation of growth from scales. Furthermore, the precise locations of their marine feeding grounds were partly unknown. Here, we were able to address the uncertainties that may have affected most earlier work: we calculated
Fig. 6. Relationships between duration of the first sea sojourn of Arctic char (Salvelinus alpinus) $(\bigcirc)$ and brown trout (Salmo trutta) (O) and (a) standardized mass-specific growth rate $\Omega\left(\% \cdot\right.$ day $^{-1}$ ) (Arctic char: $r^{2}=0.026, P>0.05$; brown trout: $\left.r^{2}=0.035, P>0.05\right)$, (b) growth increment in mass $M$ (Arctic char: $y=2.87 x-27.4 ; r^{2}=0.465, F_{[1,19]}=$ 16.49, $P=0.001$; brown trout: $y=3.89 x-63.5, r^{2}=0.338, F_{[1,19]}=9.70$, $P=0.006)$, and $(c)$ post-sojourn return rate to the River Halselva (Arctic char: $r^{2}=0.126, P>0.05$; brown trout: $r^{2}=0.020, P>0.05$ ).
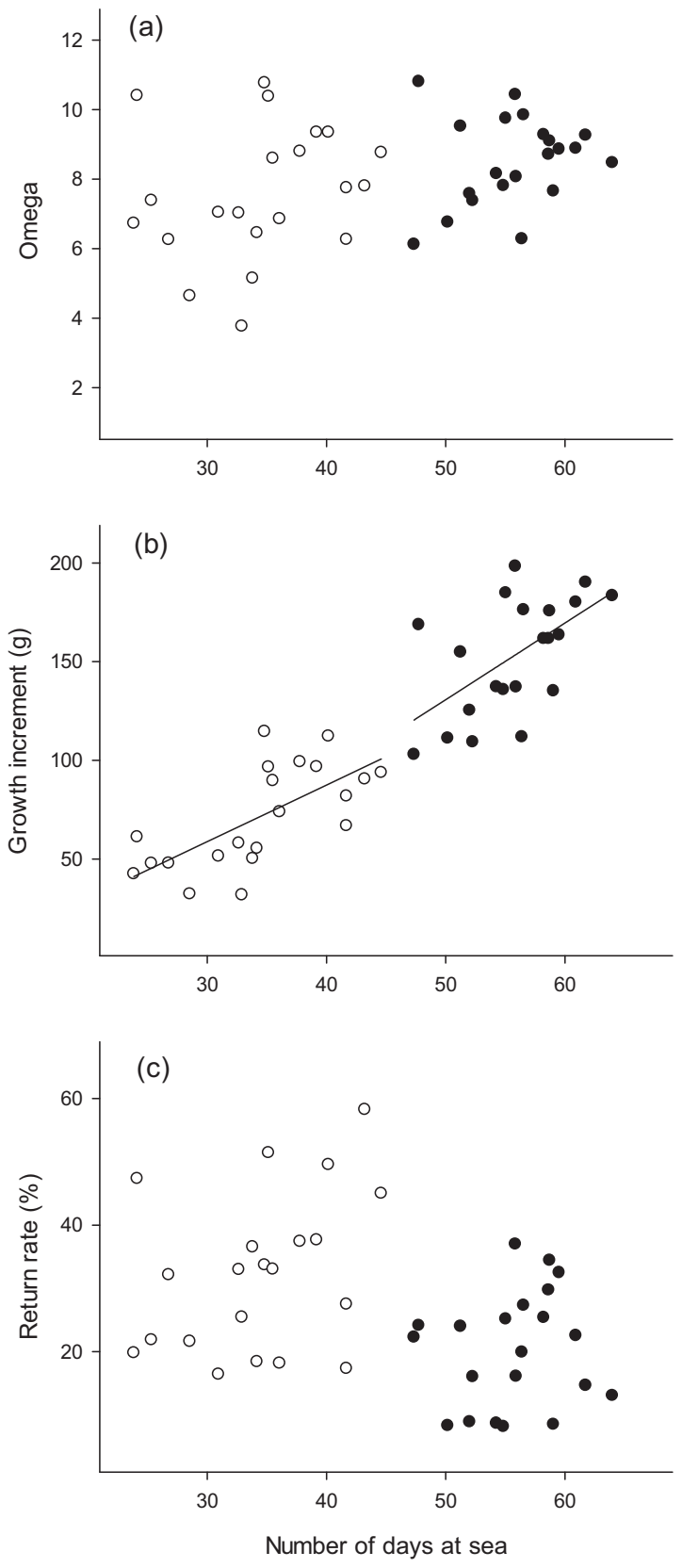

growth directly via measuring individual lengths and mass during both ascent and descent journeys and had precise data on migration and return dates and detailed information on marine feeding areas (Finstad and Heggberget 1993; Jensen et al. 2014).

Brown trout and Arctic char were broadly similar in patterns of annual marine growth and survival as well as duration of the first sea sojourn, suggesting that common marine environmental conditions and similar habitat use strategies and preferences influence the production of both fishes. Biotic factors (e.g., prey availability, predators, and parasites) and abiotic factors (e.g., sea 


\section{Pagination not final (cite DOI) / Pagination provisoire (citer le DOI)}

Fig. 7. Relationships between June mean temperature in the River Halselva and the median date of smolt descent for $(a)$ brown trout (Salmo trutta) $\left(y=-1.69 x+195, r^{2}=0.115, F_{[1,21]}=2.74, P=0.113\right)$ and (b) Arctic char (Salvelinus alpinus) $\left(y=-2.45 x+191, r^{2}=0.547, F_{[1,21]}=\right.$ 25.32, $P<0.001)$

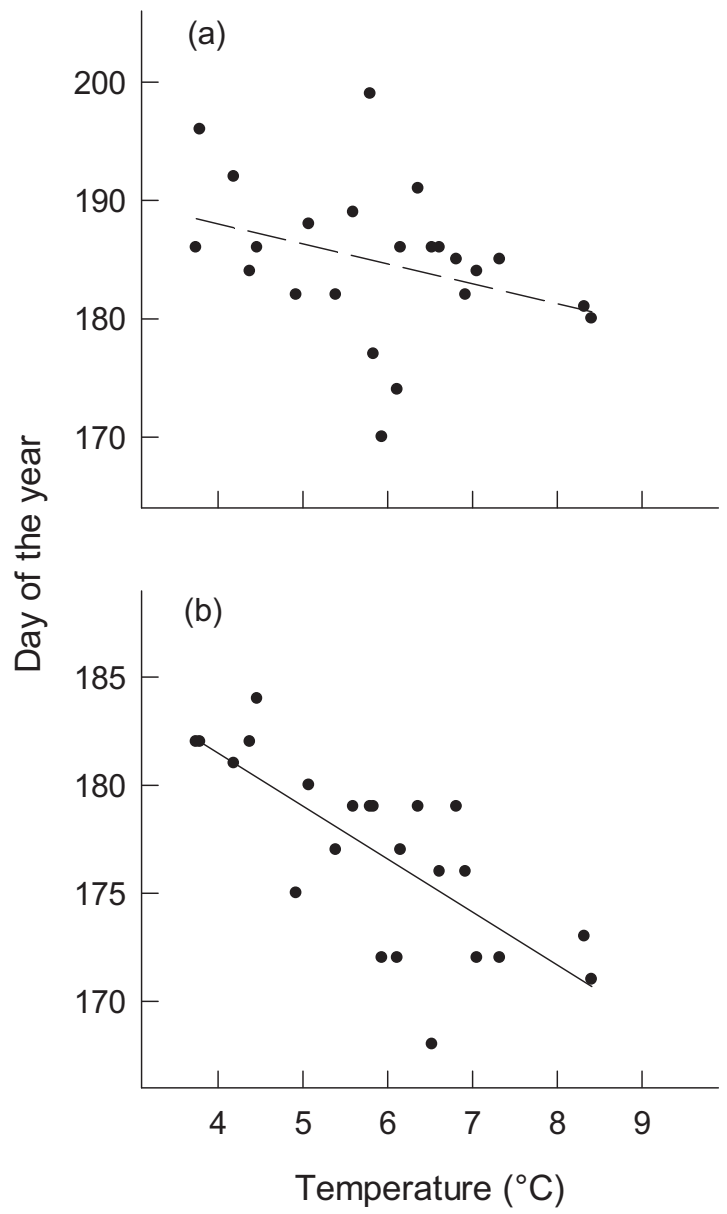

temperature) could combine to influence annual variation in fish growth and survival. High growth may improve survival either by large fish escaping through a prey handling window or by predators switching to feed on the same prey that the salmonid prey are feeding upon. Sea temperatures during the sea sojourn showed small among-year variation and were not correlated with growth of either species, leaving biotic factors as most likely explanations for variation in growth. Most $(\sim 80 \%)$ sea fishery recoveries of individually tagged brown trout and Arctic char from the River Halselva have been recorded within $30 \mathrm{~km}$ from the river mouth (Finstad and Heggberget 1993). Moreover, a recent acoustic tagging study on individuals of both species (from the same populations as the present study) confirmed that most fish feed within the fjord system (Jensen et al. 2014).

Although many factors may affect fish growth, water temperature, fish size, and energy intake (ration size, prey availability) are generally considered the most important variables (Brett et al. 1969). In the present study, the standardized mass-specific growth rate $\Omega$ was used to account for the effects of differences in initial body sizes on growth rate. For both Arctic char and brown trout, Alta Fjord temperatures were always lower than the optimal temperature for growth at maximum rations obtained in freshwater experiments (Jonsson et al. 2001; Larsson et al. 2005), and hence, positive correlations between sea temperature and marine growth was expected. However, no such relationship was found, potentially due to the relatively small among-year variation in temperatures
Fig. 8. Relationships between August mean sea temperature in the Alta Fjord and duration of the first sea sojourn for $(a)$ brown trout (Salmo trutta) $\left(y=-2.17 x+79.0, r^{2}=0.247, F_{[1,17]}=5.58, P=0.030\right)$ and (b) Arctic char (Salvelinus alpinus) $\left(y=-3.78 x+75.1, r^{2}=0.403, F_{[1,17]}=\right.$ 11.47, $P=0.004)$.

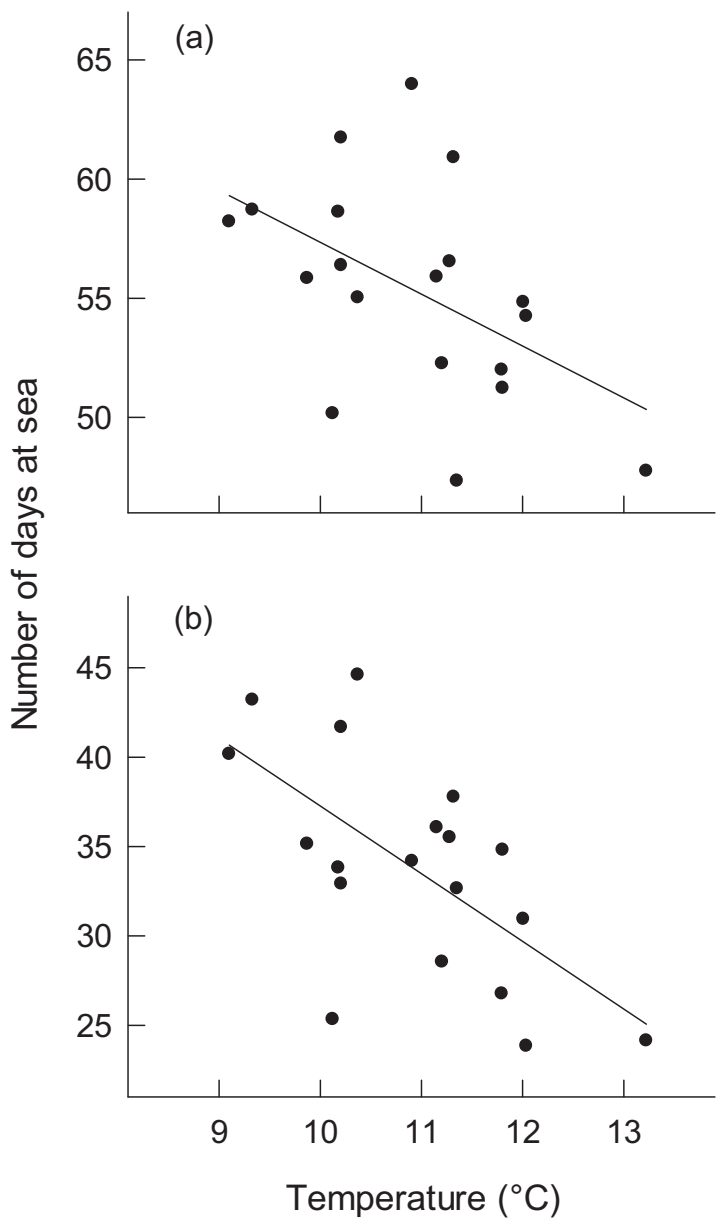

during the sea sojourn. By elimination, this suggests that energy intake (or prey availability) was the main factor affecting annual growth variations in this study.

Regardless of environment, Arctic char and brown trout are opportunistic feeders (Elliott 1994, 1997; Rikardsen et al. 2000; Klemetsen et al. 2003; Rikardsen and Amundsen 2005). Although subtle differences exist in their behaviour, at sea, both species commonly feed in shallow areas near the shore (Rikardsen et al. 2007b; Jensen et al. 2014; Thorstad et al. 2016) and spend $>90 \%$ of their time at 0-3 m depth (Rikardsen et al. 2007a). Indeed, variation in prey abundance appears to predict growth in both salmonids. Our data show that growth rates in both of the species that we studied fluctuated in ways similar to the growth fluctuations of the fish observed by Rikardsen et al. (2007b). In Rikardsen et al.'s (2007b) study, these fluctuations were correlated with variations in the abundance of herring larvae, a prime prey for the fish. Studies examining marine feeding in the Hals populations of brown trout and Arctic char revealed that herring (Clupea harengus) larvae dominated the total fish diet of both species, but the Arctic char diet also included considerable amounts of juvenile gadoids (Gadidae spp.) and sandlance (Ammodytes spp.). The same study concluded that brown trout and Arctic char diets may overlap considerably when fish larvae are superabundant in northern fjords but vary when fish larvae (especially herring) densities are low. In support, fluctuating densities of $0+$ year herring larvae during 1992-1993 (low) and 2000-2004 (3-25x higher) corre- 
sponded well to the stomach contents of brown trout and Arctic char in the Alta Fjord (Rikardsen et al. 2007b).

For both species, surrounding water temperature affected the timing of descent to the sea (river temperatures) and the duration of the first sea sojourn (fjord temperatures). In northern Norway, most of the increases to Arctic char mass and feeding occurred within the first 2-3 weeks of their sea migration and decreased throughout the summer (Berg and Berg 1989; Rikardsen et al. 2000). Rikardsen et al. (2000) suggested that this may have been due to extensive feeding on the energy-rich copepod Calanus finmarchicus and krill Thysanoessa sp. At the beginning of their migration, $C$. finmarchicus is assumed to be a key species in marine ecosystems and often represents over $90 \%$ of the total zooplankton biomass in northern and arctic areas, but the window of availability for preying on C. finmarchicus is only 4-8 weeks during early summer (Tande 1991; Halvorsen et al. 1999). High C. finmarchicus densities lead to increased fish larval growth rates and, in turn, high prey abundance for anadromous fish (Rikardsen and Dempson 2011). Earlier sea migration of smolts during warm years may be an adaptation to coincide with a correspondingly earlier zooplankton bloom. Moreover, a late-summer reduction in food rations is considered more energetically taxing during warm rather than cold years. Combined with higher predation risk at sea than in fresh water (Klemetsen et al. 2003; Hendry et al. 2004; Thorstad et al. 2016), the environmental conditions indicate that an early return to fresh water during the late summers of warm years would likely be favourable for survival.

In conclusion, despite differences in foraging strategy and habitat use, brown trout and Arctic char were significantly correlated in annual growth rate variation, sea sojourn duration, and sea survival of first-time migrants. Because both species are opportunistic feeders, they are good potential indicators of variability in marine ecosystem productivity, at least on a local scale, and may be useful for assessing the environmental impact of aquaculture, pollution, and other anthropogenic disturbances in coastal marine regions.

\section{Acknowledgements}

This study was financed by the Norwegian Environment Agency, Statkraft Energi AS, and the Norwegian Institute for Nature Research (NINA). We are very grateful to the staff at the Talvik Research Station for their invaluable assistance with traps in the River Halselva.

\section{References}

Allan, I.R.H., and Ritter, J.A. 1977. Salmonid terminology. J. Cons. Int. Explor. Mer, 37(3): 293-299. doi:10.1093/icesjms/37.3.293.

Anderson, J.T. 1988. A review of size dependent survival during pre-recruit stages of fishes in relation to recruitment. J. Northw. Atl. Fish. Sci. 8: 55-66.

Beamish, R.J., Mahnken, C., and Neville, C.M. 2004. Evidence that reduced early marine growth is associated with lower marine survival of Coho salmon. Trans. Am. Fish. Soc. 133(1): 26-33. doi:10.1577/T03-028.

Berg, O.K., and Berg, M. 1989. Sea growth and time of migration of anadromous Arctic char (Salvelinus alpinus) from the Vardnes River in northern Norway. Can. J. Fish. Aquat. Sci. 46(6): 955-960. doi:10.1139/f89-123.

Brett, J.R., Shelbourn, J.E., and Shoop, C.T. 1969. Growth rate and body composition of fingerling sockeye salmon, Oncorhynchus nerka, in relation to temperature and ration size. J. Fish. Res. Board Can. 26(9): 2363-2394. doi:10.1139/ f69-230.

Carlin, B. 1955. Tagging of salmon smolts in the river Lagan. Rep. Inst. Freshw. Res. Drottningholm, 36: 57-74.

Eldøy, S.H., Davidsen, J.G., Thorstad, E.B., Whoriskey, F., Aarestrup, K., Næsje, T.F., Rønning, L., Sjursen, A.D., Rikardsen, A.H., and Arnekleiv, J.V. 2015. Marine migration and habitat use of anadromous brown trout (Salmo trutta). Can. J. Fish. Aquat. Sci. 72(9): 1366-1378. doi:10.1139/cjfas-2014-0560.

Elliott, J.M. 1994. Quantitative ecology and the brown trout. Oxford University Press, Oxford.

Elliott, J.M. 1997. Stomach contents of adult sea trout caught in six English rivers. J. Fish Biol. 50(5): 1129-1132. doi:10.1111/j.1095-8649.1997.tb01638.x.

Elliott, J.M., Hurley, M.A., and Fryer, R.J. 1995. A new, improved growth model for brown trout, Salmo trutta. Funct. Ecol. 9(2): 290-298. doi:10.2307/2390576. Finstad, A.G., Forseth, T., Jonsson, B., Bellier, E., Hesthagen, T., Jensen, A.J., Hessen, D.O., and Foldvik, A. 2011. Competitive exclusion along climate gra- dients: energy efficiency influences the distribution of two salmonid fishes. Glob. Change Biol. 17(4): 1703-1711. doi:10.1111/j.1365-2486.2010.02335.x.

Finstad, B., and Heggberget, T.G. 1993. Migration, growth and survival of wild and hatchery-reared anadromous Arctic charr (Salvelinus alpinus) in Finnmark, northern Norway. J. Fish Biol. 43(2): 303-312. doi:10.1111/j.1095-8649.1993. tb00430.x.

Forseth, T., Letcher, B.H., and Johansen, M. 2011. The behavioural flexibility of salmon growth. In Atlantic salmon ecology. Edited by $\emptyset$. Aas, S. Einum, A. Klemetsen, and J. Skurdal. Wiley-Blackwell, Oxford. pp. 145-169.

Francis, R.I.C.C. 1990. Back-calculation of fish length: a critical review. J. Fish Biol. 36(6): 883-902. doi:10.1111/j.1095-8649.1990.tb05636.x.

Friedland, K.D., Hansen, L.P., Dunkley, D.A., and MacLean, J.C. 2000. Linkage between ocean climate, post-smolt growth, and survival of Atlantic salmon (Salmo salar L.) in the North Sea area. ICES J. Mar. Sci. 57(2): 419-429. doi:10. 1006/jmsc.1999.0639.

Friedland, K.D., MacLean, J.C., Hansen, L.P., Peyronnet, A.J., Karlsson, L., Reddin, D.G., O'Maoiléidigh, N., and McCarthy, J.L. 2009. The recruitment of Atlantic salmon in Europe. ICESJ. Mar. Sci. 66(2): 289-304. doi:10.1093/icesjms/ fsn210.

Halvorsen, E., Tande, K.S., and Høisæter, T. 1999. Physical and biological factors influencing the seasonal variation in distribution of zooplankton across the shelf of Nordvestbanken, northern Norway, 1994. Sarsia, 84(3-4): 279-292. doi:10.1080/00364827.1999.10420432.

Hendry, A.P., Bohlin, T., Jonsson, B., and Berg, O.K. 2004. To sea or not to sea? Anadromy versus non-anadromy in salmonids. In Evolution illuminated. Salmon and their relatives. Edited by S.C. Stearns and A.P. Hendry. Oxford University Press, Oxford. pp. 92-125.

Holtby, L.B., Andersen, B.C., and Kadowaki, R.K. 1990. Importance of smolt size and early ocean growth to interannual variability in marine survival of coho salmon (Oncorhynchus kisutch). Can. J. Fish. Aquat. Sci. 47(11): 2181-2194. doi:10. 1139/f90-243.

Houde, E.D. 2008. Emerging from Hjort's shadow. J. Northw. Atl. Fish. Sci. 41: 53-70. doi:10.2960/J.v41.m634.

Jensen, A.J., Finstad, B., Fiske, P., Hvidsten, N.A., Rikardsen, A.H., and Saksgård, L. 2012. Timing of smolt migration in sympatric populations of Atlantic salmon (Salmo salar), brown trout (Salmo trutta), and Arctic char (Salvelinus alpinus). Can. J. Fish. Aquat. Sci. 69(4): 711-723. doi:10.1139/f2012-005.

Jensen, A.J., Diserud, O.H., Finstad, B., Fiske, P., and Rikardsen, A.H. 2015. Between-watershed movements of two anadromous salmonids in the Arctic. Can. J. Fish. Aquat. Sci. 72(6): 855-863. doi:10.1139/cjfas-2015-0015.

Jensen, J.L.A., and Rikardsen, A.H. 2008. Do northern riverine anadromous Arctic charr Salvelinus alpinus and sea trout Salmo trutta overwinter in estuarine and marine waters? J. Fish Biol. 73(7): 1810-1818. doi:10.1111/j.1095-8649.2008. 02042.x.

Jensen, J.L.A., Rikardsen, A.H., Thorstad, E.B., Suhr, A.H., Davidsen, J.G., and Primicerio, R. 2014. Water temperatures influence the marine area use of Salvelinus alpinus and Salmo trutta. J. Fish Biol. 84(6): 1640-1653. doi:10.1111/jfb. 12366. PMID:24798261.

Jonsson, B., Forseth, T., Jensen, A.J., and Næsje, T.F. 2001. Thermal performance of juvenile Atlantic salmon, Salmo salar L. Funct. Ecol. 15(6): 701-711. doi:10. 1046/j.0269-8463.2001.00572.x.

Klemetsen, A., Amundsen, P.-A., Dempson, J.B., Jonsson, B., Jonsson, N., O'Connell, M.F., and Mortensen, E. 2003. Atlantic salmon Salmo salar L., brown trout Salmo trutta L. and Arctic charr Salvelinus alpinus (L.): a review of aspects of their life histories. Ecol. Freshw. Fish, 12(1): 1-59. doi:10.1034/j.1600-0633. 2003.00010.x.

Larsson, S., Forseth, T., Berglund, I., Jensen, A.J., Näslund, I., Elliott, J.M., and Jonsson, B. 2005. Thermal adaptation of Arctic charr: experimental studies of growth in eleven charr populations from Sweden, Norway and Britain. Freshw. Biol. 50(2): 353-368. doi:10.1111/j.1365-2427.2004.01326.x.

McCarthy, J.L., Friedland, K.D., and Hansen, L.P. 2008. Monthly indices of the post-smolt growth of Atlantic salmon from the Drammen River, Norway. J. Fish Biol. 72(7): 1572-1588. doi:10.1111/j.1095-8649.2008.01820.x.

Moss, J.H., Beauchamp, D.A., Cross, A.D., Myers, K.W., Farley, E.V., Murphy, J.M., and Helle, J.H. 2005. Evidence for size-selective mortality after the first summer of ocean growth by pink salmon. Trans. Am. Fish. Soc. 134(5): 1313-1322. doi:10.1577/T05-054.1.

Ostrovsky, I. 1995. The parabolic pattern of animal growth: determination of equation parameters and their temperature dependencies. Freshw. Biol. 33(3): 357-371. doi:10.1111/j.1365-2427.1995.tb00398.x.

Ottersen, G., and Loeng, H. 2000. Covariability in early growth and year-class strength of Barents Sea cod, haddock, and herring: the environmental link. ICES J. Mar. Sci. 57(2): 339-348. doi:10.1006/jmsc.1999.0529.

Pepin, P., Robert, D., Bouchard, C., Dower, J.F., Falardeau, M., Fortier, L., Jenkins, G.P., Leclerc, V., Levesque, K., Llopiz, J.K., Meekan, M.G., Murphy, H.M., Ringuette, M., Sirois, P., and Sponaugle, S. 2015. Once upon a larva: revisiting the relationship between feeding success and growth in fish larvae. ICES J. Mar. Sci. 72(2): 359-373. doi:10.1093/icesjms/fsu201.

Peyronnet, A., Friedland, K.D., O'Maoileidigh, N., Manning, M., and Poole, W.R. 2007. Links between patterns of marine growth and survival of Atlantic salmon Salmo salar, L. J. Fish Biol. 71(3): 684-700. doi:10.1111/j.1095-8649.2007. 01538.x.

Rikardsen, A.H., and Amundsen, P.-A. 2005. Pelagic marine feeding of Arctic 


\section{Pagination not final (cite DOI) / Pagination provisoire (citer le DOI)}

charr and sea trout. J. Fish Biol. 66(4): 1163-1166. doi:10.1111/j.0022-1112.2005. 00655.x.

Rikardsen, A.H., and Dempson, J.B. 2011. Dietary life-support: the food and feeding of Atlantic salmon at sea. In Atlantic salmon ecology. Edited by Ø. Aas, S. Einum, A. Klemetsen, and J. Skurdal. Blackwell Publishing Ltd., Oxford. pp. 115-143.

Rikardsen, A.H., and Elliott, J.M. 2000. Variations in juvenile growth, energy allocation and life-history strategies of two populations of Arctic charr in North Norway. J. Fish Biol. 56(2): 328-346. doi:10.1111/j.1095-8649.2000.tb02110.x.

Rikardsen, A.H., Amundsen, P.-A., Bjørn, P.A., and Johansen, M. 2000. Comparison of growth, diet and food consumption of sea-run and lake-dwelling Arctic charr. J. Fish Biol. 57(5): 1172-1188. doi:10.1111/j.1095-8649.2000.tb00479.x.

Rikardsen, A.H., Diserud, O.H., Elliott, J.M., Dempson, J.B., Sturlaugsson, J., and Jensen, A.J. 2007a. The marine temperature and depth preferences of Arctic charr (Salvelinus alpinus) and sea trout (Salmo trutta), as recorded by data storage tags. Fish. Oceanogr. 16(5): 436-447. doi:10.1111/j.1365-2419.2007.00445.x.
Rikardsen, A.H., Dempson, J.B., Amundsen, P.-A., Bjørn, P.A., Finstad, B., and Jensen, A.J. 2007b. Temporal variability in marine feeding of sympatric Arctic charr and sea trout. J. Fish Biol. 70(3): 837-852. doi:10.1111/j.1095-8649.2007. 01345.x.

Sigourney, D.B., Letcher, B.H., Obedzinski, M., and Cunjak, R.A. 2008. Sizeindependent growth in fishes: patterns, models and metrics. J. Fish Biol. 72(10): 2435-2455. doi:10.1111/j.1095-8649.2008.01830.x.

Tande, K.S. 1991. Calanus in North Norwegian fjords and in the Barents Sea. Polar Res. 10(2): 389-407. doi:10.1111/j.1751-8369.1991.tb00661.x.

Thorstad, E.B., Todd, C.D., Uglem, I., Bjørn, P.A., Gargan, P.G., Vollset, K.W., Halttunen, E., Kålås, S., Berg, M., and Finstad, B. 2016. Marine life of the sea trout. Mar. Biol. 163: 47. doi:10.1007/s00227-016-2820-3.

Wolf, P.A. 1951. A trap for the capture of fish and other organisms moving downstream. Trans. Am. Fish. Soc. 80(1): 41-45. doi:10.1577/1548-8659(1950)80[41: ATFTCO]2.0.CO;2. 